\title{
HUBUNGAN ANTARA REGULASI EMOSI DENGAN PERILAKU MEMAAFKAN PADA SISWA SEKOLAH MENENGAH PERTAMA
}

\author{
Dwi Astuti, Wasidi, Rita Sinthia \\ Prodi Bimbingan dan Konseling Fakultas Keguruan dan Ilmu Pendidikan \\ Universitas Bengkulu \\ dwieastuti300@gmail.com,wasidirma@unib.ac.id,ritasinthia@unib.ac.id
}

\begin{abstract}
ABSTRAK
Penelitian ini bertujuan untuk mengetahui hubungan antara regulasi emosi dengan perilaku memaafkan pada siswa kelas VIII SMP Negeri 1 Bengkulu Tengah. Sampel penelitian berjumlah 86 orang siswa yang diambil dengan teknik cluster sampling dari seluruh kelas VIII. Penelitian ini adalah penelitian deskriptif dengan teknik korelasi. Instrumen yang digunakan dalam penelitian ini adalah angket regulasi emosi dan angket perilaku memaafkan menggunakan metode skala Likert dengan 4 pilihan jawaban. Data dianalisis dengan menggunakan korelasi Pearson Product Moment. Hasil penelitian menunjukkan adanya hubungan positif yang signifikan antara regulasi emosi dengan perilaku memaafkan dengan $\mathrm{r}_{\mathrm{xy}}$ sebesar 0,667, dengan taraf signifikan sebesar $\mathrm{p}=0,000(\mathrm{p}<0,05)$. Hal ini menunjukkan bahwa terdapat hubungan positif antara regulasi emosi dengan perilaku memaafkan.
\end{abstract}

Kata kunci : regulasi emosi, perilaku memaafkan

\section{THE CORRELATION OF EMOTIONAL REGULATION TOWARDS FORGIVING BEHAVIOR IN JUNIOR HIGH SCHOOL STUDENTS}

\begin{abstract}
This research was aimed to knowing the correlation of emotional regulation towards forgiving behavior of the second grade students of SMP 1 Bengkulu Tengah. The sample of this research was 86 students which was taken by using cluster sampling technique. This research was descriptive research in which the technique was correlation. The instruments of this research were emotional regulation questionnaire and forgiving behavior questionnaire using method Likert scale with 4 answer choices. The data were analyzed by using correlation of Pearson Product Moment. The result showed that there was significant positive correlation between emotional regulation and forgiving behavior in which $r_{x y}$ was about 0,667 with the degree of significant was $\mathrm{p}=0,000(\mathrm{p}<0,05)$. This revealed that there was positive correlation between emotional regulation and forgiving behavior.
\end{abstract}

Keywords : emotional regulation, forgiving behavior 


\section{Pendahuluan}

Pendidikan merupakan segala usaha orang dewasa dalam pergaulan dengan anak-anak untuk memimpin perkembangan jasmani dan rohaninya ke arah kedewasaan (Purwanto, 2007: 11). Pendidikan berguna untuk mewujudkan keinginan, kebutuhan dan kemampuan individu sehingga tercapai pola hidup pribadi dan sosial yang baik.

Masa remaja merupakan masa peralihan antara masa kanak-kanak menuju ke masa dewasa yang ditandai dengan perubahan fisik, sosial dan emosional. Batas usia pada remaja adalah 12 tahun sampai 21 tahun (Desmita, 2010: 37). Kondisi lingkungan selalu berubah setiap saat menuntut remaja untuk dapat membina dan menyesuiakan diri dengan bentukbentuk hubungan yang baru dalam berbagai situasi, sesuai dengan peran yang dibawakannya pada saat itu dengan lebih matang. Apabila dalam penyesuian tersebut tidak berjalan dengan baik maka akan terjadi konflik pada remaja tersebut.

Konflik menjadikan individu tidak mampu mencapai kesejahteraan hidup dengan baik, dikarenakan kondisi tidak nyaman yang ditimbulkan dari konflik yang sedang dialami oleh individu. Menurut Hadriami (konflik yang dihadapi secara umum dapat disebabkan oleh berbagai faktor, seperti adanya perasaan direndahkan, dihina, tidak dihargai, pelecehan dan sebagainya (Sumiati dan Sandjaja, 2013). Pada dasarnya konflik yang seringkali terjadi menimbulkan goresan luka batin dalam diri individu yang tersakiti. Oleh karena itu, individu yang tidak mampu menyelesaikan masalah yang tengah dihadapinya, akan memumculkan berbagai emosi negatif yang tidak menyenangkan dalam dirinya. Emosi negatif tersebut dapat berupa berperilaku agresif ingin membalas dendam.

Penelitian lain yang dilakukan oleh Luskin (Nashori, 2008: 55) menyatakan bahwa individu yang memaafkan akan semakin jarang terlibat konflik. Oleh karena itu pemaafan merupakan salah satu cara dalam mencegah terjadinya konflik, pemaafakn memberikan impikasi yang besar dalam hubungan jangka pendek dan jangka panjang. Hal tersebut menerangkan bahwa memaafkan merupakan salah satu metode resoludi konflik yang efektif untuk menyelesaikan konflik secara berada, baik konflik kelompok maupun konflik interpersonal.

Menurut Dayakisni dan Hudaniah (2009: 176), memaafkan adalah tidak hadirnya afek, penilaian dan perilaku negatif serta hadirnya respon secara kognitif, afektif maupun perilaku positif terhadap pelaku yang telah berlaku tidak adil atau menyakitkan. Menurut 
McCullought (2006), aspek-aspek perilaku memaafkan yaitu motivasi menghindar, motivasi balas dendam dan motivasi berdamai.

Menurut Wade dan Worthington (2003), ada beberapa faktor yang berpengaruh terhadap perilaku memaafkan yaitu empati, respon pelaku, kualitas hubungan, merenung dan mengingat (rumination), komitmen agama, faktor personal dan kecerdasan emosi. Kecerdasan emosi merupakan kemampuan untuk memahami keadaan emosi diri sendiri dan orang lain. Mampu mengendalikan emosi, memanfaatkan emosi dalam membuat keputusan, perencanaan dan memberikan motivasi. Seseorang yang mampu mengendalikan emosi dengan baik cenderung lebih mudah untuk memaafkan kesalahan orang lain.

Menurut Gross (2002), regulasi emosi adalah kemampuan yang dimiliki seseorang untuk menilai, mengatasi, mengelola dan mengungkapkan emosi yang tepat untuk mencapai keseimbangan emosional. Kemampuan yang tinggi dalam mengelola emosi akan meningkatkan kemampuan individu untuk menghadapi ketegangan dalam kehidupannya. Menurut Thompson (Rasjid, 2012), aspek-aspek regulasi emosi yaitu memonitori emosi, mengevaluasi emosi, dan memodifikasi emosi.

Menurut Burney (Paramitasari dan Alfian, 2012), ekspresi emosional yang sehat (kontrol kemarahan) menunjukkan strategi manajemen kemarahan yang baik dan belajar untuk mencari solusi positif untuk menghadapi suatu masalah. Perilaku memaafkan digunakan oleh remaja untuk bisa melepaskan semua beban penderitaan agar mereka tidak menyimpan dendam, menanggung beban pikiran, dan perasaan sakit. Hasil penelitian menunjukkan bahwa seseorang yang dapat memaafkan mengalami penurunan kemarahan, kecemasan dan depresi yang signifikan. Begitupun sebaliknya seseorang yang tidak mampu mengendalikan emosi dengan baik akan berperilaku agresif hingga membahayakan keselamat individu.

Hasil observasi pada sekolah SMP Negeri 1 Bengkulu Tengah terjadi perilaku agresif berupa perkelahian antar siswa. Perkelahian tersebut bermula dari DI mengejek FR dengan kata-kata botak karena FR memotong rambut sangat pendek. FR tidak terima dan sakit hati terhadap perlakukan DI sehingga FR meninju DI. DI pun membalas perlakukan FR sehingga terjadi perkelahian saling tinju antara 2 orang siswa tersebut.

Hasil wawancara dengan guru BK yang peneliti lakukan di SMP Negeri 1 Bengkulu Tengah, begitu banyak fenomena-fenomena atau permasalahan yang ada disekolah tersebut, dari yang malas belajar, keluar masuk kelas di jam pelajaran, membolos, berkelahi/cekcok 
mulut antar teman dan lain-lain. Salah satu permasalahan yang menarik untuk diteliti yaitu mengenai perkelahian/cekcok mulut antar siswa. Banyak siswa yang menceritakan kepada guru BK jika perkelahian/cekcok mulut antar siswa terjadi akibat saling mengejek yang menimbulkan perasaan sakit hati dan kemarahan. Hal tersebut menimbulkan terjadinya permusuhan hingga perkelahian antar siswa. Masalah dalam penelitian ini yaitu "Apakah terdapat hubungan antara regulasi emosi dengan perilaku memaafkan pada siswa kelas VIII di SMP Negeri 1 Bengkulu Tengah?”.

Penelitian ini bertujuan untuk mengetahui apakah terdapat hubungan postif yang signifikan antara regulasi emosi dengan perilaku memaafkan pada siswa kelas VIII di SMP Negeri 1 Bengkulu Tengah.

\section{Metode Penelitian}

Desain penelitian ini menggunakan desain deskripsi kuantitatif, dengan teknik korelasi. Populasi yang digunakan pada penelitian ini adalah siswa kelas VIII di SMP Negeri 1 Bengkulu Tengah yang berjumlah 288 siswa. Teknik pengambilan sampel yaitu dengan cluster sampling. Sampel dalam penelitian ini terbagi menjadi dua yaitu sampel uji coba dan sampel penelitian. Sampel uji coba yang digunakan dalam penelitian ini yaitu satu kelas sebanyak 30 siswa selain sampel penelitian. Sampel penelitian yang digunakan yaitu tiga kelas sebanyak 86 siswa penentuan sampel ini berdasarkan rumus Slovin (Sarjono dan Julianita, 2013: 30), dengan taraf kesalahan 10\%.

Teknik pengumpulan data yang digunakan dalam penelitian ini adalah angket. Angket adalah suatu daftar yang berisi pertanyaan-pertanyaan yang harus dijawab atau dikerjakan oleh responden atau orang/anak yang ingin diselidiki (Walgito, 2010: 72). Kedua angket tersebut menggunakan metode Skala Likert, dengan menyediakan empat alternatif jawaban, yaitu Selalu (SL), Sering (S), Jarang Sekali (JS), dan Tidak Pernah (TP) dan terdiri dari pernyataan favorable (pernyataan positif)dan unfavorable (pernyataan negatif) terhadap objek sikap. Sebelum angket diberikan kepada sampel penelitian angket tersebut di uji validitas, daya pembeda dan reliabilitas. Uji validitas dilakukan oleh dua orang ahli. Dari hasil uji daya pembeda pada variabel perilaku memaafkan yang berjumlah 30 pernyataan terdapat 7 item yang tidak memenuhi syarat daya pembeda sedangkan pada variabel regulasi emosi yang berjumlah 35 item terdapat 9 item yang tidak memenuhi syarat daya pembeda. Hasil uji reliabilitas pada variabel regulasi emosi diperoleh nilai Cronbach's Alpha $=0,863$ dan pada variabel regulasi emosi diperoleh nilai Cronbach's Alpha $=0,829$. Data yang 
diperoleh dari sampel penelitian kemudian dianalisis menggunakan teknik analisis deskripstif, uji normalitas, uji linieritas dan uji hipotesis menggunakan pearson product moment.

\section{Hasil dan Pembahasan}

Deskripsi data pada bagian ini adalah deskripsi tentang masing-masing variabel, yang diteliti yaitu perilaku memaafkan (Y) dengan regulasi emosi (X). Deskripsi tentang perilaku memaafkandan regulasi emosi diperoleh dari hasil penyebaran kuesioner ke sejumlah responden yang menjadi sampel penelitian.

a. Deskrpisi data perilaku memaafkan

Berdasarkan skor yang diperoleh, didapatkan gambaran umum skor perilaku memaafkan yang dihitung berdasarkan skor ideal. Gambaran umum tersebut dapat dilihat pada Tabel 1.

Tabel 1

Deskripsi Perilaku Memaafkan

\begin{tabular}{lc}
\hline Jumlah Sampel $(\mathrm{N})$ & 86 \\
\hline Skor Minimum & 60 \\
\hline Skor Maximum & 81 \\
\hline Rata-rata $(\mu)$ & 69,93 \\
\hline
\end{tabular}

Pada Tabel 1 deskripsi perilaku memaafkan diperoleh gambaran tentang perilaku memaafkan dengan jumlah sampel sebanyak 86 orang siswa, skor minimum sebesar 60, skor maximum sebesar 81, dan nilai rata-rata sebesar 69,93. Selanjutnya skor-skor di kategorisasi. Subjek digolongkan ke dalam tiga kategori perilaku memaafkan yaitu tinggi, sedang, dan rendah.

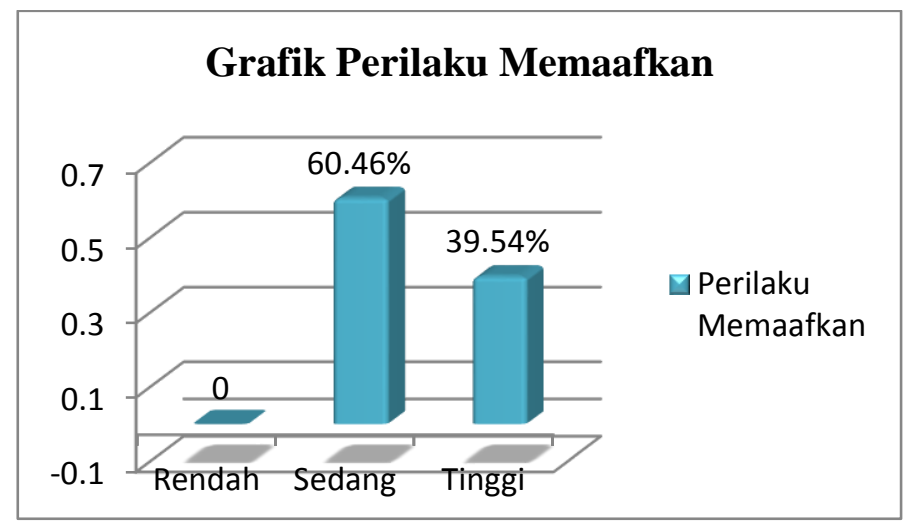

Gambar 1. Grafik Perilaku Memaafkan 
Berdasarkan Gambar 1. grafik perilaku memaafkan dapat dilihat bahwa subjek yang memilki perilaku memaafkan rendah tidak ada, subjek yang memilki perilaku memaafkan sedang sebanyak 60,46\% dan subjek yang memiliki perilaku memaafkan tinggi sebanyak 39,54\%. Jadi dapat di simpulkan bahwa pada sampel penelitian ini perilaku memaafkan pada kategori sedang lebih mendominasi.

b. Deskrpisi data regulasi emosi

Berdasarkan skor yang diperoleh, didapatkan gambaran umum skor regulasi emosi yang dihitung berdasarkan skor ideal. Gambaran umum tersebut dapat dilihat pada Tabel 2.

Tabel 2

Deskripsi Regulasi Emosi

\begin{tabular}{lc}
\hline Jumlah Sampel $(\mathrm{N})$ & 86 \\
\hline Skor Minimum & 70 \\
\hline Skor Maximum & 96 \\
\hline Rata-rata $(\mu)$ & 82,26 \\
\hline
\end{tabular}

Pada Tabel 2. Deskripsi regulasi emosi diperoleh gambaran tentang regulasi emosi dengan jumlah sampel sebanyak 86 orang siswa, skor minimum sebesar 70, skor maximum sebesar 96, nilai rata-rata sebesar 82,26. Subjek digolongkan ke dalam tiga kategori regulasi emosi yaitu tinggi, sedang, dan rendah.

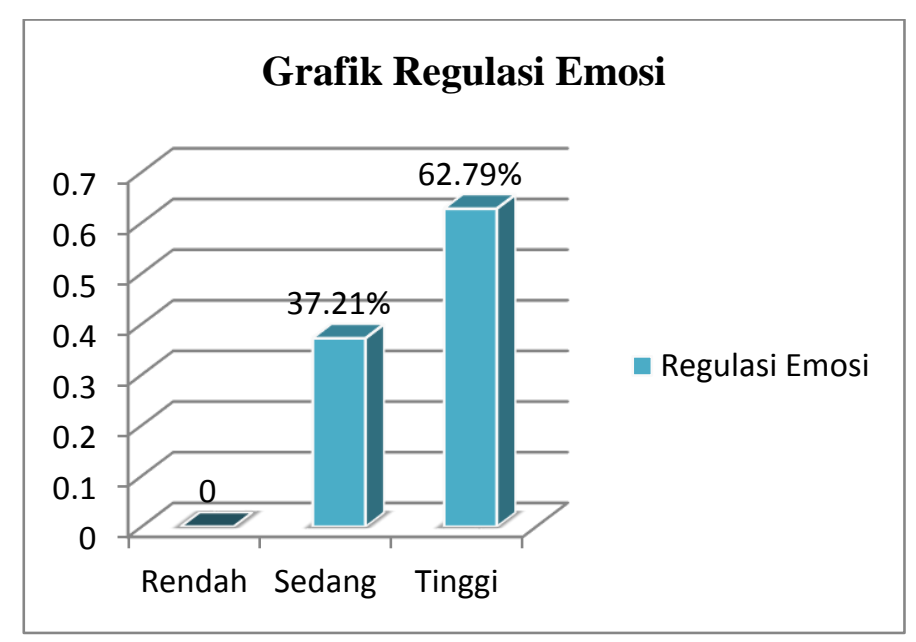

Gambar 2. Grafik Regulasi Emosi

Berdasarkan Gambar 2. Grafik regulasi emosi dapat dilihat bahwa subjek yang memilki regulasi emosi rendah tidak ada, subjek yang memilki regulasi emosi sedang sebanyak $47,21 \%$ dan subjek yang memiliki regulasi emosi tinggi sebanyak 62,79\%. Jadi dapat di simpulkan bahwa pada sampel penelitian ini regulasi emosi pada kategori tinggi lebih mendominasi. 
Tabel 3

Kategorisasi Data Regulasi Emosi dengan Perilaku Memaafkan

\begin{tabular}{cccc}
\hline No & Kategori & Frekuensi & Persentase \\
\hline $\mathbf{1}$ & Sedang - Sedang & 29 & $33,73 \%$ \\
\hline $\mathbf{2}$ & Sedang - Tinggi & 3 & $3,48 \%$ \\
\hline $\mathbf{3}$ & Tinggi - Sedang & 23 & $26,74 \%$ \\
\hline $\mathbf{4}$ & Tinggi - Tinggi & 31 & $36,05 \%$ \\
\hline
\end{tabular}

Pada Tabel 3. Kategorisasi data regulasi emosi dengan perilaku memaafkan menunjukkan bahwa subjek yang memilki regulasi emosi sedang dengan perilaku memaafkan sedang yaitu sebanyak 29 orang $(33,73 \%)$, subjek yang memiliki regulasi emosi sedang dengan perilaku memaafkan tinggi yaitu sebanyak 3 orang $(3,48 \%)$, subjek yang memiliki regulasi emosi tinggi dengan perilaku memaafkan sedang sebanyak 23 orang $(26,74)$, dan subjek yang memiliki regulasi emosi tinggi dengan perilaku memaafkan tinggi yaitu sebanyak 31 orang $(36,05 \%)$.

Sebelum menguji hipotesis, terlebih dahulu dilakukan uji prasyarat analisis sebagai syarat sebelum melakukan uji hipotesis penelitian dengan jumlah sampel sebanyak 86 siswa. Uji prasyarat analisis tersebut meliputi analisis deskriptif, uji normalitas dan uji linieritas.

Hasil analisis deskriptif pada variabel perilaku memaafkan nilai rata-rata 69,93, nilai median sebesar 69, nilai modus sebesar 68, dan standar deviasi 5,00. Pada variabel regulasi emosi menunjukan nilai rata-rata 82,26, nilai median sebesar 81 , nilai modus sebesar 87 dan nilai standar deviasi sebesar 6,29. Uji normalitas menunjukkan skor Kolmogorov Smirnov variabel perilaku memaafkan 1,115 dengan p =0,166 (p>0,05) sedangkan skor Kolmogorov Smirnov variabel regulasi emosi 1,083 dengan $\mathrm{p}=0,192(\mathrm{p}>0,05)$ yang berarti variabel perilaku memaafkan dan regulasi emosi memiliki distribusi normal. Uji linieritas hubungan antara regulasi emosi dengan perilaku memaafkan menghasilkan $\mathrm{F}_{\text {lin }}=64,094$ dengan nilai signifikasi $0,000(p<0,05)$. Nilai $F$ penyimpangan linieritas sebesar 0,792 dengan $p=0,707$ $(>0,05)$ menunjukkan adanya hubungan linier antara variabel regulasi emosi dengan perilaku memaafkan.

Berdasarkan hasil uji hipotesis menggunakan analisis korelasi pearson product moment, diperoleh koefisien korelasi antara regulasi emosi dengan perilaku memaafkan sebesar 0,667 dengan $\mathrm{p}=0,000(\mathrm{p}<0,05)$, menunjukan bahwa terdapat hubungan positif yang signifikan antara regulasi emosi dengan perilaku memaafkan. 
Berdasarkan hasil analisis data yang dikemukakan dan dari hasil pengujian hipotesis ternyata hipotesis diterima keberadaanya bahwa terdapat hubungan positif yang signifikan antara regulasi emosi dengan perilaku memaafkan dengan nilai $r_{x y}$ sebesar 0,667 dan $p=0,000$ ( $<<0,05)$. Hasil ini menunjukan bahwa regulasi emosi mempengaruhi perilaku memaafkan. Dari hasil penelitian menunjukkan regulasi emosi yang dimiliki siswa tergolong tinggi sehingga siswa cenderung lebih mudah untuk memberi maaf kepada orang yang telah menyakiti. Perilaku memaafkan siswa yang tergolong dalam kategori sedang ini terjadi karena dilihat pada hasil angket yang diberikan pada siswa terlihat bahwa pada indikator membalas dendam skor yang di dapat menunjukkan hasil yang rendah yaitu pada pernyataan nomor 8 "Saya membalas semua perlakukan orang yang telah menyakiti" dengan jumlah skor 186, pernyataan nomor 9 "Saya berharap sesuatu yang buruk terjadi kepada orang yang telah menyakiti" dengan jumlah skor 182 dan pernyataan nomor 12 "Saya tetap membencinya karena telah menyakiti” dengan skor 181. Namun, hasil penelitian menunjukkan bahwa regulasi emosi tinggi tetapi perilaku memaafkan sedang. Tingginya regulasi emosi pada siswa kelas VIII ini terjadi karena rata-rata individu mengikuti berbagai ektrakurikuler yang ada di sekolah seperti ektrakurikuler paskibraka, pramuka, bola voli, bola basket, karate, pik-r dan lain-lain sehingga individu tersebut dapat menyalurkan emosinya terhadap hal-hal yang bersifat positif.

Secara teoritis hasil penelitian ini dapat dijelaskan berdasarkan aspek-aspek yang terdapat dalam regulasi emosi, yaitu memonitor emosi,mengevaluasi emosi, dan memodifikasi emosi. Regulasi emosi pada aspek memonitori emosi yang paling baik dalam meningkatkan perilaku memaafkan siswa adalah ketika individu mampu menyadari emosi yang muncul pada diri individu. Aspek ini dapat membantu individu menjadi lebih mampu untuk mengenali emosi yang muncul. Evaluasi ini memperlihatkan bagaimana individu mampu menyadari dan memahami emosi yang muncul sehingga individu mampu menamakan setiap emosi yang muncul. Penilaian tersebut terlihat ketika individu terhubung dengan emosi-emosi, pikiran dan dapat menamakan setiap emosi yang muncul.

Regulasi emosi dianggap penting dalam perkembangan siswa, erat kaitannya dengan dampak negatif yang muncul jika siswa tidak mampu meregulasi emosi dengan baik. Siswa akan mengalami kesulitan dalam menampilkan perilaku sosialnya dan bahkan menciptakan pencitraan yang buruk. Siswa akan memperoleh kesuksesan dalam menampilkan perilaku sosialnya, dan membentuk citra yang baik apabila kemampuan meregulasi emosi siswa dapat terpenuhi secara baik, kematangan emosi yang cukup yang ditandai dengan kemampuan 
memaafkan pada siswa. Siswa yang menyadari dirinya dalam emosi negatif akan berusaha menghindari situasi yang akan memperburuk emosi yang akan terjadi pada dirinya atau berusaha untuk mengkomunikasikan kesalahan yang akan dilakukan orang lain pada dirinya.

Regulasi emosi pada aspek mengevaluasi emosi yang paling berperan dalam meningkatkan perilaku memaafkan adalah ketika siswa mampu untuk mengelola dan menyeimbangkan emosi-emosi yang dialami. Kemampuan mengelola emosi khususnya emosi negatif seperti kemarahan, kesedihan, kekecewaan, dendam dan benci akan membuat individu tidak terbawa dan terpengaruh secara mendalam. Sebagaimana didapatkan pada penelitian ini, siswa mampu mengelola amarahnya untuk tidak diluapkan begitu saja dan lebih memilih untuk menahan emosi negatif yang dialami individu.

Regulasi emosi pada aspek memodifikasi emosi yang paling berperan dalam menentukan tinggi rendahnya perilaku memaafkan adalah kemampuan siswa dalam mengubah emosi positif dan emosi negatif. Pada penelitian ini siswa mampu tetap berpikir jernih ketika sedang cemas, meredam kemarahan, mengambil air wudhu lalu solat ketika sedang marah, dan mampu menyembunyikan kemarahan dari orang lain.

\section{Kesimpulan}

Hasil analisis korelasi menunjukkan nilai $\mathrm{r}_{\mathrm{xy}}$ sebesar 0,667 dan $\mathrm{p}=0,000(\mathrm{p}<0,05)$ yang berarti hipotesis diterima, maka terdapat hubungan positif yang signifikan antara regulasi emosi dengan perilaku memaafkan pada siswa kelas VIII SMP Negeri 1 Bengkulu Tengah. Hal ini dapat dilihat dari hasil angket regulasi emosi yang tergolong tinggi dan perilaku memaafkan yang tergolong sedang. Perilaku memaafkan tergolong sedang disebabkan pada indikator membalas dendam hasil angket yang diperoleh tergolong rendah yang berarti siswa di SMP Negeri 1 Bengkulu Tengah termasuk siswa yang memilki rasa ingin membalas dendam terhadap perlakuan orang yang telah menyakiti.

Diharapkan bagi pihak sekolah dapat mengembangkan hasil penelitian dengan melakukan berbagai macam kegiatan positif yang berkaitan dengan regulasi emosi dan perilaku memaafkan. Bagi guru bimbigan dan konseling hendaknya dapat meningkatkan perillaku memaafkan dengan cara meregulasi emosi melalui pemberian layanan dan kegiatan pendukung bimbingan dan konseling. Bagi penelitian selanjutnya jika ingin hasil yang lebih maksimal dalam meningkatkan perilaku memaafkan dapat dilakukan melalui pemberian treatment beberapa layanan bimbingan dan konseling. 


\section{Daftar Pustaka}

Dayakisni, T \& Hudania. (2015). Psikologi Sosial. Malang : UMM Press.

Desmita. (2010). Psikologi Perkembangan Peserta Didik. Bandung : Remaja Rosdakarya.

Gross, J.J. (2002). "Emotion Regulation : Affective, Cognitve, and Social Consequences". Jurnal Psychophysiology, 39 (2002), 281-291.

McChullought, M.E., Root, L. M., \& Cohen. A.D. (2006). "Writing About the Benefit of an Interpersonal Transgression Facilitates Forgiveness". Journal of Consulting and Clinical Psychology, 74(5), 887-897.

Nashori, F. (2008). Psikologi Sosial Islam. Bandung: Rafika Aditama.

Paramitasari, R \& Alfian, I.N. (2012). "Hubungan Antara Kematangan Emosi dengan Kecenderungan Memaafkan pada Remaja Akhir". Jurnal Psikologi Pendidikan dan Perkembangan, 1(2). 170-182.

Purwanto, N. (2007). Ilmu Pendidikan Teoretis dan Praktis. Bandung : Remaja Rosdakarya.

Rasjid, M. (2012). "Hubungan Antara Peer Attachment dengan Regulasi Emosi Remaja yang Menjadi Siswa Di Boarding School SMA Negeri 10 Samarinda". Jurnal Psikologi Pendidikan, 1(3), 1-7.

Sarjono, H \& Julianita, W. (2013). SPSS vs LISREl Sebuah Pengantar, Aplikasi untuk Riset. Jakarta: Salemba Empat.

Sumiati, I \& Sandjaja, S.S. (2013). "Hubungan Antara Memaafkan dengan Kematangan Diri Pada Remaja Akhir”. Jurnal NEOTIC Psychology, 3(2), 144-162.

Walgito, B. (2010). Bimbingan dan Konseling (Studi dan Karier). Yogyakarta: Andi Offset. 